\title{
INSTRUMENTAL AND DIAGNOSTIC CRITERIA OF HEMODYNAMIC DISORDERS AND ENDOTHELIAL DYSFUNCTION CORRECTION IN PREGNANTS WITH ARTERIAL HYPERTENSION
}

\author{
S. M. Heryak, I. Ye. Humenna
} I. YA. HORBACHEVSKY TERNOPIL STATE MEDICAL UNIVERSITY, TERNOPIL, UKRAINE

\begin{abstract}
Background. According to the WHO, hypertension is associated with 20-33\% of maternal death during pregnancy within extragenital pathology statistics. There are complications of the fetus and newborn associated with hypertension at 140/90 $\mathrm{mm} \mathrm{Hg}$ and higher.

Objective. A comparative analysis of antihypertensive therapy effectiveness in pregnants with arterial hypertension was performed using modern clinical and instrumental methods of endothelial function diagnostic, central and utero-placental hemodynamic estimation.

Methods. We examined 63 pregnant women with hypertension at 28 to 32 weeks of gestation. Women were randomized into three groups:group I (control group - 20 women), that included pregnant women with hypertension treated with basic antihypertensive therapy as recommended by Health Ministry of Ukraine standards (metildofa and nifedipin); group II - 21 pregnant women receiving metildofa and metoprolol; group III (22 pregnant women) receiving metildofa and nebivolol.

Conclusions. It was found that the brachial artery ultrasound measuring and occlusive plethysmography procedure by Dietz is an early and safe method of endothelial dysfunction diagnostic in pregnants with hypertension. Doppler ultrasound of blood flow in uterine, umbilical arteries, and middle cerebral arteries of the fetus allows timely diagnosis of the side effect of antihypertensive drugs on the fetus. The therapy of choice for pregnants with Stage II Arterial Hypertension should be based on methyldopa and calcium channel antagonists or selective beta-blockers combination. Highly selective beta-blockers with vasodilative effect (nebivolol hydrochloride) and L-arginine (Tivortin) allow to prevent perinatal adverse effects of antihypertensive therapy, to correct hemodynamic disorders and endothelial dysfunction in pregnants with arterial hypertension.
\end{abstract}

KEY WORDS: arterial hypertension, uterine-placental hemodynamics, endothelial dysfunction.

\section{Introduction}

According to the $\mathrm{WHO}$, hypertension is associated with $20-33 \%$ of maternal death during pregnancy within extragenital pathology statistic. There are complications of the fetus and newborn associated with hypertension at $140 / 90 \mathrm{~mm} \mathrm{Hg}$ and higher $[1,5,7]$. Mechanisms of increased blood pressure, leading to hypertension and/or strengthening of symptoms during pregnancy are very diverse. A major role of endothelial dysfunction (ED) in the development of hypertension is shown in the recent years. It is characterized by reduced synthesis of nitric oxide as one of the main vasodilators [3, 8, 9]. Unfortunately, ongoing antihypertensive therapy does not improve pregnancy outcomes for the fetus, and even lead to higher frequency of low weight for gestational age newborns. Overall, high blood pressure decreases due to drug therapy and may improve pregnancy Address for correspondence: S.M. Heryak, Medical Biochemistry Department, m. Voli, 1, Ternopil, 46001, Ukraine

Tel.: +380 352254891 outcomes for the mother but not for the fetus $[4,6$, 11]. Antihypertensive drug therapy choice during pregnancy is metyldophamine as it was proved to be safe for the fetus. The second-line drugs include calcium channel blockers. They are recommended for the treatment of high arterial blood pressure in pregnant females when refractory hypertension to methyldopa therapy occurs $[2,12]$. The antihypertensive drugs of the second line for pregnant women also include $\beta$-blockers, but their use is limited due to the development of adverse effects to the fetus $[1,2,10]$. It is necessary to choose an optimal set of long-term antihypertensive treatment for pregnant women which will not have a negative effect on the fetus. That is why it is very important to perform detailed comparative analysis of differential approaches to the treatment of hypertension during pregnancy and perinatal complications.

The aim is to investigate endothelial dysfunction in pregnants with hypertension using non-invasive instrumental methods and offer an optimal therapy program for pregnants with arterial hypertension and 
to minimize the negative impact of the antihypertensive drugs on fetus.

\section{Methods}

We examined 63 pregnant women with hypertension at 28 to 32 weeks of gestation, which were hospitalized to the Ternopil Regional Perinatal Center "Mother and Child" of the Department of extragenital pathology for pregnant.

Clinical research was performed for all pregnant women according to the Ministry of Health of Ukraine standards: clinical analysis of blood and urine, biochemical blood analysis, assessment of urinary albumin excretion to detect microalbuminuria, as well as ECG, echocardiography, ultrasound investigation of renal and peripheral vessels.

We used modified technique by Dietz N. M. (1996) [6, 10], based on the measurement of the diameter of the vessel (by ultrasound) and peripheral vascular resistance (occlusal plethysmography), in order to assess endothelial function and its effect on uteroplacental hemodynamic.

Initially, the brachial artery diameter (distance between opposite walls of the artery) was measured in systole phase via linear $7 \mathrm{MHz}$ sensor. Then arterial blood pressure was measured with classic manual tonometer. The pressure, equal to systolic plus $50 \mathrm{~mm} \mathrm{Hg}$, was injected into the cuff for 5 minutes. Measuring of the artery diameter was carried out immediately and again after 10 minutes.

Cardiotocography (CTG) with a score on a Fisher' scale and biophysical profile were used to assess the functional status of the fetus. The development of the fetus was evaluated by comparing ultrasonic fetometry under percentile tables in dynamic survey of 4 weeks after the previous test. Blood flow was assessed at uterine arteries, umbilical arteries, and middle cerebral arteries of the fetus with ultrasonic Doppler.

Women were randomized into three groups: group I (control group - 20 women), which included pregnant women with hypertension treated with basic antihypertensive therapy as recommended by $\mathrm{MOH}$ Ukraine standards (metildofa and nifedipin); group
II - 21 pregnant women receiving metildofa and metoprolol;group III (22 pregnant women) receiving metildofa and nebivolol. Pregnants of all three groups were treated orally with low-dose aspirin, calcium supplements, and magnesium for the prevention of preeclampsia according to the Ministry of Health of Ukraine standards.

Statistical analysis: data analysis was done and verified using Statsoft STATISTICA 10 at Systemic Statistical Analysis Department of Ternopil State Medical University.

\section{Results}

Basic antihypertensive therapy for all groups included dopegit four times a day. Women of the Group I were treated with nifedipin $20 \mathrm{mg}$ per day in four divided doses to stabilize blood pressure. Pregnants of the Group II were treated with metoprolol at a dose of $25 \mathrm{mg}$ per day in two divided doses. Pregnant women of the Group III were prescribed nebivolol hydrochloride $5 \mathrm{mg}$ once a day as a highly selective third generation beta blocker with vasodilative properties and ability to modulate the synthesis of the nitric oxide by the blood vessels endothelium. The endothelial dysfunction treatment should be considered as a strategic line for effective prevention of cardiovascular complications of the arterial hypertension as pregnancy treatment. Therefore, women of the second and the third groups were administered L-arginine aspartate (Tivortin) $1 \mathrm{~g}$ $(5 \mathrm{ml})$ orally six times per day for 14 days in addition to antihypertensive preparations.

The gestational term of 28-32 weeks and arterial hypertension stage II were the criterions for randomization. Study groups were homogeneous for age, obstetric history, and the course of the underlying disease. Exclusion criteria were defined as following: hypertension stage III, severe concomitant extragenital pathology (diabetes, diseases of the thyroid gland, other cardiovascular pathology).

We observed different hemodynamic normalization and stability of blood pressure after treatment in each group (Table 1).

Table 1. Blood pressure and heart rate in women of the surveyed groups during dynamic treatment $(\mathrm{M} \pm \mathrm{m})$

\begin{tabular}{|c|c|c|c|c|}
\hline \multirow{2}{*}{ Group } & $\begin{array}{c}\text { Term of } \\
\text { examination }\end{array}$ & $\begin{array}{c}\text { SBP, } \\
\mathrm{mm} \mathrm{Hg} .\end{array}$ & $\begin{array}{c}\text { DBP, } \\
\mathrm{mm} \mathrm{Hg} .\end{array}$ & $\begin{array}{c}\text { HR, } \\
\text { Bpm }\end{array}$ \\
\hline \multirow{2}{*}{ Group I, $\mathrm{n}=20$} & Before treatment & $156.2 \pm 0.39$ & $108.8 \pm 1.08$ & $92.0 \pm 0.81$ \\
\cline { 2 - 5 } & After treatment & $137.2 \pm 1.42$ & $91.4 \pm 1.24$ & $92.0 \pm 0.94$ \\
\hline \multirow{2}{*}{ Group II, $\mathrm{n}=21$} & Before treatment & $154.8 \pm 0.32$ & $106.4 \pm 0.59$ & $91.0 \pm 0.81$ \\
\cline { 2 - 5 } & After treatment & $138.2 \pm 0.98$ & $92.2 \pm 1.43$ & $68.0 \pm 1.50$ \\
\hline \multirow{2}{*}{ Group III, $\mathrm{n}=22$} & Before treatment & $156.8 \pm 0.52$ & $108.8 \pm 0.92$ & $90.0 \pm 0.88$ \\
\cline { 2 - 5 } & After treatment & $130.2 \pm 1.26$ & $82.6 \pm 1.12$ & $80.0 \pm 1.56$ \\
\hline
\end{tabular}

Note: $p<0.01$ - data accuracy. 
Pregnant women of the Group I showed poor tolerability to the therapy. Particularly, we observed sudden changes in blood pressure (hypotension episodes below 100/60 mm Hg or hypertensive crises (blood pressure above $160 / 110 \mathrm{~mm} \mathrm{Hg}$ ) in three pregnant women; four pregnant women developed swelling and redness of the face, seven women complained about palpitations, dizziness and weakness.

Simultaneously, eight patients of the second group experienced bradycardia (less than $60 \mathrm{bpm}$ ), while another five complained about dyssomnia, dizziness, weakness, and increased edema.

The best tolerability to the therapy was observed in the third group, where only two pregnant women noted weakness and headache while the heart rate slowed down below $60 \mathrm{bpm}$ in two women. Also, as it is shown in Table 1, the clinically most effective scheme of arterial pressure normalization was the combination of nebivolol hydrochloride and metildofa on the background intake of L-arginine.

Forty four $(70.9 \%)$ of the surveyed women experienced ECG changes before treatment: the deviation of the electrical axis of the heart to the left, ST segment depression, inversions or flattening of T wave in leads II, III and avF. In pregnants of the Group I tachyarrhythmia was observed, including seven women $(36.8 \%)$ with arrhythmias. Bradyarhythmia and conduction disturbances (different degrees of blockages) were observed in nine pregnants of the Group II (42.9\%). Conduction disorders and slowing heart rate were observed in six women of the third group (27.2\%).

As for results of the sonogram of the heart, ejection fraction in all three groups before treatment was $63.3 \% \pm 3.4 \%$, and it decreased insignificantly after the treatment only in the second group. All females in all three groups (38 females, $62.1 \%$ ) were equally affected by end-diastolic increase in the size of the right ventricle, and an increase of the index of left ventricular mass by $10-15 \%$. Ten pregnant women $(16.1 \%)$ showed increase of the index of the left ventricular mass from 15.1 to $27.8 \%$, which may be classified as excessive. Combined preeclampsia developed in seven females (two pregnants from the first group, three from the second group, and two from the third group).

Data for the indicators of the endothelial function are presented in Table 2.

In all three groups, the diameter of the brachial artery before treatment should be assessed as narrowed. Therefore, an endothelial dysfunction is observed in pregnants with hypertension, which is manifested by spasm of the arteries. There was a significant dilatation of the brachial artery with slow normalization of arterial tonicity for the Group I after the treatment (diameter $4.4 \mathrm{~mm} \pm 0.2 \mathrm{~mm}$ and endothelium-dependent dilatation was more than $22 \%$, which is relatively higher than in healthy pregnant women). Pregnants of the second group experienced spasm of the arteries, and this condition did not normalize. As for the third group, the diameter of the brachial artery was significantly restored to the values close to the healthy pregnant women and endothelium-dependent vasodilation (18.4\%) showed a normal tone of arteries and their ability to respond adequately to stimulation. Therefore, the endothelial function was restored in the Group III of patients to the highest level.

We have also established a relationship between fetometric performance relative to the gestational

Table 2. Indicators of the endothelial function $(M \pm m)$

\begin{tabular}{|l|c|c|c|}
\hline \multirow{2}{*}{ Group } & Term examination & $\begin{array}{c}\text { Initial brachial artery } \\
\text { diameter, } \mathrm{mm}\end{array}$ & $\begin{array}{c}\text { Endothelium dependent } \\
\text { vasodilation, } \% .\end{array}$ \\
\hline \multirow{2}{*}{ Group I } & Before treatment & $3.41 \pm 0.04$ & $8.0 \pm 0.31$ \\
\cline { 2 - 4 } & After treatment & $4.14 \pm 0.04$ & $22.4 \pm 0.51$ \\
\hline \multirow{2}{*}{ Group II } & Before treatment & $3.33 \pm 0.05$ & $8.2 \pm 0.32$ \\
\cline { 2 - 4 } & After treatment & $3.38 \pm 0.05$ & $5.0 \pm 0.47$ \\
\cline { 2 - 4 } Group III & Before treatment & $3.37 \pm 0.04$ & $8.1 \pm 0.29$ \\
\cline { 2 - 4 } & After treatment & $3.80 \pm 0.03$ & $18.4 \pm 0.47$ \\
\hline
\end{tabular}

Note: $p<0.01$ - data accuracy

Table 3. The main parameters of fetometry during treatment of pregnants with hypertension of 32-34 weeks term $(M \pm m)$

\begin{tabular}{|l|c|c|c|c|}
\hline \multirow{2}{*}{ Group } & Term examination & $\begin{array}{c}\text { Biparietal diameter } \\
(\mathrm{BPD}), \mathrm{mm}\end{array}$ & $\begin{array}{c}\text { Abdominal diameter } \\
(\mathrm{AD}), \mathrm{mm}\end{array}$ & $\begin{array}{c}\text { Femur length } \\
(\mathrm{FL}), \mathrm{mm}\end{array}$ \\
\hline \multirow{2}{*}{ Group I, $\mathrm{n}=20$} & Before treatment & $79.06 \pm 0.17$ & $79.64 \pm 0.89$ & $48.56 \pm 0.48$ \\
\cline { 2 - 5 } & After treatment & $84.42 \pm 0.95$ & $87.36 \pm 1.19$ & $62.05 \pm 0.99$ \\
\hline \multirow{2}{*}{ Group II, $\mathrm{n}=21$} & Before treatment & $78.27 \pm 0.21$ & $79.15 \pm 0.38$ & $48.16 \pm 0.28$ \\
\cline { 2 - 5 } & After treatment & $82.30 \pm 0.86$ & $84.24 \pm 0.90$ & $60.03 \pm 1.23$ \\
\hline \multirow{2}{*}{ Group III, $\mathrm{n}=22$} & Before treatment & $78.01 \pm 0.22$ & $79.10 \pm 0.19$ & $48.30 \pm 0.45$ \\
\cline { 2 - 5 } & After treatment & $86.30 \pm 0.74$ & $91.20 \pm 0.84$ & $65.24 \pm 0.77$ \\
\hline
\end{tabular}
S. M. Heryak et al.


term and the option of antihypertensive therapy on the basis of surveys (Table 3).

The size and weight of the fetus is less than average in the general population according to the gestational age in women with hypertension, which is often due to the disruption of hemodynamics in the mother-placenta-fetus system. Therefore, according to the ultrasound examination of the surveyed patients, the average biparietal diameter decreased for a given gestational age and evidence about disruption of uteroplacental hemodynamics; morevover, after the treatment, biparietal diameter was the biggest in the third group, followed by the first group and the second group. As for indicative parameters such as average diameter of the abdomen and femur length, best values were observed in the third group that explains normal fetal fatness and skeleton development, and therefore the optimal normalization of utero-placental hemodynamics, which correlated with indicators of endothelial function. Thus, the maximum normalization of the biometric parameters was observed in the third group of pregnant women.

Doppler velocimetry is helpful to evaluate blood circulation in the placenta and detect early signs of poor circulation. To assess the blood circulation, the following indices are used: systolic-diastolic ratio (SDR), pulsation index (PI) and index of resistance (IR), all of those are shown in Table 4.

The degree of hemodynamic disorders in the mother-placenta-fetus system is evaluated according to the Medvedev classification: $1 \mathrm{~A}$ - isolated violations of the utero-placental blood flow; $1 \mathrm{~B}$ - isolated violations of the feto-placental circulation; II - violation of utero- placental and feto-placental circulation does not reach the critical meanings; III-decompensated disorders and circulatory centralization.

Based on our results, we can conclude that pregnant women of the Group I experienced slight improvement of the parameters of the uterine artery blood flow, but no significant improvement of blood flow in the umbilical artery and middle cerebral artery of the fetus. Pregnant women of the second group showed insignificant worsening of the blood flow in the uterine arteries, umbilical artery and middle cerebral artery. Pregnant women of the third group were characterized by a slight improvement in blood flow of the uterine artery and nonsignificant improvement in umbilical artery and middle cerebral artery of the fetus.

Table 4. Doppler velocimetry in surveyed groups of pregnant women after $\mathbf{3 0}$ weeks of gestation

\begin{tabular}{|l|c|c|c|c|}
\hline & Indicators & Uterine artery & Umbilical artery & $\begin{array}{c}\text { Fetal middle cerebral } \\
\text { artery }\end{array}$ \\
\hline \multirow{3}{*}{ Group I, $\mathrm{n}=20$} & $\mathrm{SDR}$ & $2.10 \pm 0.011$ & $2.98 \pm 0.017$ & $5.6 \pm 0.017$ \\
\cline { 2 - 5 } & $\mathrm{PI}$ & $0.93 \pm 0.008$ & $0.84 \pm 0.015$ & $1.68 \pm 0.020$ \\
\cline { 2 - 5 } & $\mathrm{IR}$ & $0.68 \pm 0.004$ & $0.57 \pm 0.006$ & $0.62 \pm 0.006$ \\
\hline \multirow{3}{*}{ Group II, $\mathrm{n}=21$} & $\mathrm{SDR}$ & $1.78 \pm 0.016$ & $2.88 \pm 0.016$ & $5.41 \pm 0.030$ \\
\cline { 2 - 5 } & $\mathrm{PI}$ & $0.83 \pm 0.015$ & $0.72 \pm 0.016$ & $1.46 \pm 0.020$ \\
\cline { 2 - 5 } Group III, $\mathrm{n}=22$ & $\mathrm{IR}$ & $0.78 \pm 0.006$ & $0.67 \pm 0.006$ & $0.72 \pm 0.005$ \\
\cline { 2 - 5 } & $\mathrm{SDR}$ & $1.76 \pm 0.001$ & $2.82 \pm 0.006$ & $5.40 \pm 0.024$ \\
\cline { 2 - 5 } & $\mathrm{PI}$ & $0.81 \pm 0.015$ & $0.72 \pm 0.015$ & $1.44 \pm 0.020$ \\
\hline
\end{tabular}

Note: $p<0.01$ - statistical significance and data accuracy.

\section{Discussion}

Summing up the results of the abovementioned surveys, we can assume that in order to minimize side effects during gestation, the cardioselective $\beta$-blockers with vasodilation properties should be preferred. These drugs will prevent the increase in total peripheral vascular resistance and can smooth the negative effects of classical beta blockers (delayed intrauterine development, bradycardia, hypotension, hypoglycemia, respiratory depression of the fetus).

\section{Conclusions}

1. It was found that the brachial artery ultrasound measuring and occlusive plethysmography procedure by Dietz is an early and safe method of endo- thelial dysfunction diagnostic in pregnants with hypertension. Doppler ultrasound of blood flow in uterine arteries, umbilical arteries and middle cerebral arteries of the fetus allows timely to reveal the side effect of antihypertensive drugs on the fetus.

2. The therapy of choice for pregnants with Stage II Arterial Hypertension should be based on methyldopa and calcium channel antagonists or selective beta-blockers combination.

3. Highly selective beta-blockers with vasodilative effect (nebivolol hydrochloride) and L-arginine (Tivortin) let us to prevent perinatal adverse effects of antihypertensive therapy, to correct hemodynamic disorders and endothelial dysfunction in pregnants with arterial hypertension. 


\section{References}

1. Наказ МО3 України № 676: Гіпертензивні розлади під час вагітності; 31.12.2004.

2. Наказ МО3 України № 384: Про затвердження та впровадження медико-технологічних документів зі стандартизації медичної допомоги при артеріальній гіпертензії; 24.05.2012.

3. Медведь ВІ Вибрані лекції з екстрагенітальної патології вагітних; Київ; 2010: 10-240.

4. Пристром АМ, Пацеев СВ, Примакова АМ, Фомин ОЮ Место небиволола среди бета-адреноблокаторов в лечении мягкой (умеренной) артериальной гипертензии у беременных. Медицинские новости 2013; 2: 70-75.

5. Авраменко ТВ, Коломійченко ТВ, Янюта Саар М Застосування Тівортіну у комплексному лікуванні вагітних з хронічною артеріальною гіпертензією. Здоровье женщины 2012; 4 (70): 62-65.

6. Запорожан ВМ, Луцкер ОЛ, Коньков ДГ, Галич СР Спосіб неінвазивної діагностики функціонального стану ендотелію при вагітності. Патенти України. Номер патенту: 77984. Заявлено: 19.06.2012. Опубліковано: 11.03.2013.

7. Henriques ACPT, Carvalho FHC, Feitosa HN, Macena RHM, Mota RMS, Alencar JCG. Endothelial dysfunction after pregnancy-induced hypertension. Int $\mathrm{J}$ Gyn Ob 2014; 124 (3): 230-234.

8. Mosca L. et al. Effectiveness-based guidelines for the prevention of cardiovascular disease in women -2011 update: a guideline from American Heart Association. Circulation 2011; 123 (11): 1243-1262.

9. Morton JS, Davidge ST Arterial endotheliumderived hyperpolarization: potential role in pregnancy adaptations and complications. Journal Cardiovasc. Pharmacol 2013; 61(3): 197-203.

10. Dietz NM, Engelke KA, Halliwill JR, Proctor DN, Joyner MJ Contribution of nitric oxide and prostaglandins to reactive hyperemia in human forearm. J. Appl. Physiol 1996; 81(4): 1807-1814.

11. Yinon Y, Kingdom JC, Odutayo A, Moineddin R, Drewlo S, Lai V, Cherney DZ, Hladunewich MA. Vascular dysfunction in women with a history of preeclampsia and intrauterine growth restriction: insights into future vascular risk. Circulation 2010; 122: 1846-1853.

12. Romundstad PR, Magnussen EB, Smith GD, Vatten LJ. Hypertension in pregnancy and later cardiovascular risk: common antecedents? Circulation 2010; 122 : 579-584. 